\title{
Reconciliation as ritual: comparative perspectives on innovation and performance in processes of reconciliation
}

\author{
ROXANA WATERSON
}

In the past three decades, extraordinary developments have taken place in a number of countries making a transition from authoritarian regimes to democratic governments. ${ }^{1}$ This has given rise to the emergent field of study of transitional justice. ${ }^{2}$ As for the best means of achieving such transitions, debates are still vigorous about the relative merits of truth and reconciliation commissions (TRCs) versus criminal proceedings, whether in the context of the International Criminal Court at The Hague or of hybrid national/international special courts such as the Extraordinary Chambers in the Courts of Cambodia (ECCC) in Phnom Penh, which is currently trying five former high-ranking members of the Khmer Rouge. TRCs are relatively new political and legal phenomena. Patricia Hayner lists 21 truth commissions formed since 1974- the most successful of which to date appear to have been those in Chile and South Africa. ${ }^{3}$ She provides an excellent analysis of how these commissions have differed from one another and what they have achieved. Still, many urgent questions remain about how best to ensure the efficacy of the process. ${ }^{4}$

\footnotetext{
1 An earlier version of this article was presented in the Seminar Series at the Centre for Cross-Cultural Research, Research School of the Humanities, The Australian National University, Canberra, on 26 October 2007. I am grateful to the audience on that occasion for their feedback and especially to Rosanne Kennedy and to the journal's two anonymous readers for their further editorial suggestions.

2 See Kritz, Neil (ed.) 1995, Transitional Justice: How emerging democracies reckon with former regimes, United States Institute of Peace Press, Washington, DC; McAdams, A. James (ed.) 1997, Transitional Justice and the Rule of Law in Democracies, Notre Dame University Press, Notre Dame, Ind.; Roht-Arriaza, Naomi and Mariezcurrena, Javier (eds) 2006, Transitional Justice in the Twenty-First Century: Beyond truth versus justice, Cambridge University Press, Cambridge.

3 Hayner, Patricia 2001, Unspeakable Truths: Confronting state terror and atrocity, Routledge, New York, pp. 291-305.

4 For a fuller discussion, see Caruth, Cathy (ed.) 1995, Trauma: Explorations in memory, Johns Hopkins University Press, Baltimore; Minow, Martha 2000, 'The hope for healing: what can truth commissions do?', in Robert Rotberg and Dennis Thompson (eds), Truth v. Justice: The morality of truth commissions, Princeton University Press, Princeton, NJ, pp. 235-60; Hayner, Unspeakable Truths. All these works offer searching
} 
Questions of social memory-deciding how to remember the past, in order to deal with the future - lie at the heart of all these endeavours. The efforts to enact transitional justice have focused on the felt need to uncover hidden memories of past traumas and to break the culture of silence and impunity created by terror. The question of how people are to continue living together after atrocities have been committed is of profound moral import, but the drive towards reconciliation is complicated by many factors: the political fragility of a new regime, the extent to which those who constituted or benefited from the old order remain in positions of power, the continuing power relations between groups who have come to see one another as enemies, or the hindrances even to establishing what really happened, and thus what it is that a nation should be coming to terms with. In each case, the particular socio-political context is unique. Furthermore, processes of transitional justice generally depart in significant ways from already established legal procedures. TRCs, for instance, even when established by law, typically have a somewhat ambiguous relationship with the justice system, and it is not a foregone conclusion that they will 'work' or their outcomes be considered binding. They are formed in response to specific events and are aiming to achieve something that has never been tried before in that society. Hence they demand a great deal of innovation, and their outcomes are necessarily uncertain. When people innovate, however, they can also find it useful to seek legitimacy in certain ideas, models or precedents that are already available to them within their own cultural repertoire.

A factor that as yet has not received all the attention it deserves, therefore, is the question of how, in each context, the cultural resources that people have to draw on in processes of reconciliation must be different. ${ }^{5}$ What I want to argue here is that TRCs must function on two levels at once: the legal and the ritual. Legal authority, and an articulation with an existing system of justice, is essential for a commission to do its work of getting at the truth (or at least, in the words of historian John Lukacs, to contribute to 'the reduction of untruth') and for its findings to be taken seriously. ${ }^{6}$ The work towards reconciliation,

\footnotetext{
insights into questions of trauma and healing, how much a truth commission can reasonably be expected to accomplish and the possible psychological benefits (or conversely, additional trauma) that survivors can hope to gain from knowing the truth, however painful.

5 The same applies in the closely related field of conflict resolution. This is by now an internationally recognised technique for working with disputants - for instance, in workshops designed to help them find ways to communicate with each other or to train third-party negotiators. Its development has followed various models, not necessarily paying significant attention to cultural factors, and sometimes deliberately attempting to set them aside. Kevin Avruch, a professor of anthropology at George Mason University and faculty member of its Institute for Conflict Analysis and Resolution, is one of those who, on the contrary, has argued forcefully for the inescapable need to take account of culture in such dealings if they are to succeed (see Avruch, Kevin 1998, Culture and Conflict Resolution, United States Institute of Peace Press, Washington, DC).

6 Lukacs, John 1968 [1994], Historical Consciousness: The remembered past, Transaction Publishers, New Brunswick/London, p. 357.
} 
however, requires the creation simultaneously of an appropriate ritual setting and it is here that the insights of anthropology into the workings of ritual might usefully be applied.

Rituals - as has often been observed by anthropologists - sometimes serve the conservative purpose of reinforcing the status quo, and they tend to gain dignity and efficacy through repetition. ${ }^{7}$ In contrast, a recent paper by Leo Howe stresses the high degree of risk entailed in the staging of some ritual performances, the very outcomes of which are the result of political struggles between the participants. ${ }^{8}$ Clearly, in the case of reconciliation procedures, we are at the extreme end of the risk continuum, since these are rites in which the stakes are high, there are no comforting precedents to fall back on, some might be at best reluctant participants and efficacy cannot be determined in advance. Insofar as a TRC sets out to help a community move out of a place of cultural trauma ${ }^{9}$ and barbarity ${ }^{10}$ towards the re-establishment of moral decency, it might usefully be viewed as a sort of rite of passage. ${ }^{11}$ Passage to where is here a difficult question; the road is long and it is naive to suppose that 'reincorporation', in van Gennep's terms, can be achieved fully within the time frame of a commission. Moreover, even if some elements of ritual structure and sacredness might be crucial to success, this still has to be held in balance with a certain necessary openness. Reconciliation cannot be forced, and the most genuine gestures in this direction, if they occur at all, are likely to be spontaneous and unpredictable. If the ritual were to become too choreographed, it might seem to offer nothing but hollow rhetoric and thus defeat its own purpose. The question I therefore wish to pose is this: within the unique social context in which each TRC must operate, what sort of resources might be available to participants, in the form of culturally salient ideas and values that they can bring to bear on the process - ideas that can help to invest it with meaning, even a degree of sanctity, and that might assist people in 'knowing what they are doing' and feeling their way towards the difficult goal of reconciliation? Problematic as the process of reconciliation clearly is, I want to argue that such cultural resources can indeed vary quite markedly, and that they might have a very distinct bearing on outcomes. I will illustrate my discussion by drawing on three contrasting examples: South Africa, Indonesia and Timor-Leste.

7 Bloch, Maurice 1974, 'Symbol, song, dance, and features of articulation: or is religion an extreme form of traditional authority?', Archives Européenes de Sociologie, vol. 15, pp. 55-81.

8 Howe, Leo 2000, 'Risk, ritual and performance', Journal of the Royal Anthropological Institute, vol. 6, no. 1, pp. 63-79.

9 Alexander, Jeffrey 2004, 'Toward a theory of cultural trauma', in J. Alexander et al. (eds), Cultural Trauma and Collective Identity, University of California Press, Berkeley, pp. 1-30.

10 Bhargava, Rajeev 2000, 'Restoring decency to barbaric societies', in Rotberg and Thompson, Truth $v$. Justice, pp. 45-67.

11 On rites of passage, see van Gennep, Arnold 1909 [1960], The Rites of Passage, Routledge, London; Turner, Victor 1969, The Ritual Process: Structure and anti-structure, Routledge, London; and Turner, Victor 1974, Dramas, Fields, and Metaphors: Symbolic action in human society, Cornell University Press, Ithaca. 
While truth might be a goal that can to some degree be measured in terms of the documentation achieved by a commission and the contents of its final report, its partner, reconciliation, is bound to be much more elusive. Not all truth commissions even set out to concern themselves with reconciliationalthough the South African one specifically did so. Where reconciliation is a goal, however, it cannot be detached so easily from the issue of truth. Evidence is anecdotal, but survivors in whatever social context appear to want most of all that perpetrators should explain what they did and their motivations for doing it, accept responsibility for their deeds and show genuine remorse. ${ }^{12}$ Without that, reconciliation is hardly meaningful, but there is no guarantee that perpetrators will come to it; they might, on the contrary, seek ways to paint themselves as victims or even as heroes of the nation. No-one, not even a TRC, has the right to demand that victims reconcile with or forgive those who have harmed them. As Archbishop Desmond Tutu said of the South African TRC, which he headed, its stated aim could only be the promotion of reconciliation, not its achievement, for anything else would have been unrealistic and morally invalid. Interestingly though, this position was one that he reached somewhat far into the process, for from the beginning much had been made of the commission's moral goal of reconciliation. ${ }^{13}$ In a searching assessment of what the TRC did achieve, the authors in a subsequent book of reflections made the point that this could be regarded only as the beginning of a process. ${ }^{14}$ Addressing the structural injustices brought about by apartheid's long-term skewing of the South African economy remains the biggest challenge to be met - one that threatens continuing progress towards reconciliation if it should be too long delayed. ${ }^{15}$ Frustration about continuing poverty and deprivation did indeed boil over into violent protests in Johannesburg in May 2008.

While TRCs must have some legal basis in being formally established by an act of parliament or presidential decree, it is interesting to note that their relations with the justice system are likely to be ambivalent. From a comparative point of view, the examples I am considering also vary in the nature of this relationship. In the South African case, de Lange noted that the commission was empowered to bypass the justice system in granting amnesty to those it felt had made full disclosure and also in naming perpetrators before they had been convicted.

12 Hayner, Unspeakable Truths, p. 157; Burgess, Patrick 2006, 'A new approach to restorative justice-East Timor's Community Reconciliation Processes', in Roht-Arriaza and Mariezcurrena, Transitional Justice in the Twenty-First Century, p. 188.

13 Hayner, Unspeakable Truths, p. 156.

14 See Villa-Vilencio, Charles and Verwoerd, Wilhelm 2000, Looking Back, Reaching Forward: Reflections on the Truth and Reconciliation Commission of South Africa, University of Cape Town Press/Zed Books, Cape Town/London.

15 De Lange, Johnny 2000, 'The historical context, legal origins and philosophical foundation of the South African Truth and Reconciliation Commission', in Villa-Vilencio and Verwoerd, Looking Back, Reaching Forward, pp. 14-31; Terreblanche, Sampie 2000, 'Dealing with systematic economic injustice', in VillaVilencio and Verwoerd, Looking Back, Reaching Forward, pp. 265-76. 
The threat of prosecution remained for those who were deemed not to have disclosed fully to the TRC. Some prosecutions were held during the life of the commission and this 'fed directly into the TRC process by convincing many wavering perpetrators that they were on their own and that it would be in their best interests to testify'. ${ }^{16}$ Given that there was a high degree of continuity in the personnel of state institutions after the transition, however, that meant handing prosecutions to the perpetrators, because those who had been deeply implicated in the apartheid regime, in its police and security forces, would now be responsible for investigating their own human rights offences. Besides being slow and expensive, therefore, there was no guarantee that these trials could secure convictions - and indeed some of them did fail. ${ }^{17}$

If de Lange could say of South Africa that 'the whole legal order suffers from a serious crisis of credibility, legitimacy, and efficiency', how much more is this the case in Indonesia, post-Suharto? Under the government of Abdurrahman Wahid, a law was tabled in 2000 to mandate the setting up of a truth commission to examine the events of 1965-66, but it was not passed until close to the end of Megawati Sukarnoputri's presidency, in 2004. ${ }^{18}$ The government of Susilo Bambang Yudhoyono got as far as appointing a panel to select candidates to serve as commissioners, but in 2006, the validity of the new law was contested by a group of non-governmental organisations, some of whom objected to the idea of amnesty for perpetrators. In a shock verdict, the Constitutional Court then annulled the law in December 2006. ${ }^{19}$ The Law on Human Rights Courts of 2000 also led to the establishment of an Ad Hoc Court to hear cases relating to Timor-Leste. Only 18 individuals have been tried as a result of this process; there have been 16 acquittals, one acquittal on appeal and only one person convicted - a Timorese militia leader, Euricco Guterres, who received a 10-year sentence for crimes against humanity. Not surprisingly, the Indonesian trials have been the subject of strong international criticism. ${ }^{20}$

\footnotetext{
16 De Lange, 'The historical context, legal origins and philosophical foundation of the South African Truth and Reconciliation Commission', pp. 28-9.

17 For instance, Magnus Malan, the former Minister of Defence, was tried unsuccessfully after he refused to apply for amnesty.

18 The counter-coup that brought Suharto to power was accompanied by massacres in which between 500000 and 1 million suspected communists and alleged communist sympathisers were brutally murdered (see Cribb, Robert [ed.] 1990, The Indonesian Killings of 1965-66: Studies from Java and Bali.Volume 21, Monash Papers on Southeast Asia, Centre for Southeast Asian Studies, Monash University, Clayton, Victoria; Robinson, Geoffrey 1995, The Dark Side of Paradise: Political violence in Bali, Cornell University Press, Ithaca; Zurburchen, Mary [ed.] 2005, Beginning to Remember: The past in the Indonesian present, NUS Press, Singapore). 19 Sulistiyanto, Priambudi and Setyadi, Rumekso 2007, Civil society and grassroots reconciliation in Central Java, Indonesia, Paper presented at the Conference In Search of Reconciliation and Peace in Indonesia and East Timor, ARI, National University of Singapore, Singapore, 18-20 July 2007 (to appear in Bräuchler, Birgit [ed.] 2009, Reconciliation from Below: Grassroots initiatives in Indonesia, Routledge, London).

20 See Burgess, 'A new approach to restorative justice', p. 200.
} 
While the Indonesian judiciary remains weak and ineffectual, the situation in Timor-Leste itself has been much more difficult. Its judicial system was staffed almost in its entirety by Indonesians; all the judges and nearly all the lawyers left after the population voted overwhelmingly for independence from Indonesia in 1999. ${ }^{21}$ Hence the decision to adopt a hybrid system in pursuit of truth and justice - one that involved efforts to pursue criminal justice through the Serious Crimes Unit and the setting up of a Commission for Reception, Truth and Reconciliation (Comissão de Acolhimento, Verdade e Reconciliação, CAVR), whose task was to focus on documentation and efforts at reconciliation between victims and perpetrators of less grave offences. The CAVR ran for 39 months from April 2002, submitting its final report in March 2006. ${ }^{22}$ The prosecution procedures utilised national and international personnel, although, by Reiger's account, the interactions between them were far from sufficient, the operation was haphazardly planned and hampered by inadequate funding and no money was available for public outreach to inform a largely non-literate and widely scattered population of the results of the proceedings. Another obstacle was the continuing condition of lawlessness after the separation; the fledgling justice system they were trying to rebuild was soon overwhelmed with hundreds of new cases at the same time as it attempted to address the past. The Special Panels of the Dili District Court set up by the UN Transitional Administration for East Timor (UNTAET) in mid-2000 to try 'serious criminal offences' from the 1974-99 period eventually did succeed in indicting 400 people, but since 339 of them remained at large in Indonesia, the results hardly did much to satisfy Timorese desires for justice. It is in this context that one must consider the innovative attempts of the CAVR to facilitate some level of reconciliation between victims and lesser perpetrators at the level of local communities. A particularly interesting feature of this commission was its drawing on indigenous traditional methods of dispute settlement to create a meaningful, ritual framework for the enactment of reconciliation. Although Timor-Leste is a staunchly Catholic country, the cultural resources deployed in this instance thus belonged to traditions older than the world religions.

\section{South Africa}

Arguably by far the most effective TRC to date has been South Africa's, which ran from 1996 to 1998 and heard evidence from 20000 victims of apartheid and more than 7000 perpetrators. Yet, remarkable as it was, even this commission has not been judged an unqualified success. In 2006, Tutu, who had presided

21 See Reiger, Caitlin 2006, 'Hybrid attempts at accountability for serious crimes in Timore Leste', in Roht-Arriaza and Mariezcurrena, Transitional Justice in the Twenty-First Century, pp. 143-75.

22 Burgess, 'A new approach to restorative justice', p. 183. 
over the commission, declared his regret that it had let perpetrators off too lightly and had not done enough to end the culture of impunity that was the legacy of apartheid. In particular, there was some bitterness in South Africa that many more black than white perpetrators were prepared to testify, and a feeling that white South Africans did not pay as much attention to the work of the TRC as they should have, even though its hearings, televised daily, reached an audience of millions. All the same, after the TRC, it is impossible for white beneficiaries of apartheid to claim ignorance or disbelief about the violence by which the system had been maintained. This in itself is a great achievement for South Africa, since a number of earlier TRCs in other countries had not dared to hold their hearings publicly for fear that they would be too inflammatory and would invite military retaliation. ${ }^{23}$

The establishment of the TRC offered great political and legal advantages in that, by offering amnesty only on condition of full disclosure, it provided an incentive for perpetrators to admit as fully as possible what they knew. If they had been tried in a court of law, they would have been entitled to a defence lawyer whose task would have been to deny the guilt of his client and ensure that as little information as possible about past atrocities was revealed. The TRC, in contrast, produced a large volume of new testimony, breaking the culture of silence and enabling many victims' relatives finally to find out what had happened to their loved ones. The felt need to address wider social distress in a way that criminal proceedings cannot is well expressed by De Lange, who notes that the most important human factor is the hurt and humiliation that many have suffered, and the inability of courts or inquests to bring some relief to that hurt' ${ }^{24}$ The performative possibilities for the commission to address and acknowledge the hurt in a way that a trial could not are among its most interesting features. ${ }^{25}$

A TRC, unlike a legal trial, grants agency not only to those who are invited to testify, but to the audience, who must become engaged as witnesses to the testimony. The structure of such events is designed to create a space conducive to testifying - by survivors and perpetrators - and to appropriate acknowledgment by an audience. Martha Minow stresses the importance of solidarity and 'a moral, sympathetic, and politically attentive stance' on the part of the witness in the testimonial, just as in the therapeutic relationship. ${ }^{26}$ Proceedings in a court of law do of course share in the performative, as the very

\footnotetext{
23 Rotberg and Thompson, Truth v. Justice, p. 5.

24 De Lange, 'The historical context, legal origins and philosophical foundation of the South African Truth and Reconciliation Commission', p. 30.

25 Because of its ability to capture performance in a way that text cannot, film here becomes an important and vivid medium for preservation and study of such proceedings. Deborah Hoffman and Frances Reid's remarkable film Long Night's Journey into Day (Iris Films in association with Cinemax Reel Life, 95 mins, 2000) enables viewers to grasp how the commission was supposed to work, as well as offering visual clues about the relative sincerity of particular perpetrators.

26 Minow, 'The hope for healing', p. 245.
} 
existence of the genre of courtroom drama serves to demonstrate. The public hearings of a TRC can likewise be viewed at one level as a form of theatre in which the audience becomes the recipient of testimony. ${ }^{27}$ Minow and MarlinCuriel have indeed argued that the presence of the audience, and its empathetic attention (what Marlin-Curiel has dubbed its 'response-ability'), is an essential precondition for such proceedings to have any hope of efficacy - either for the survivors or for the society as a whole. ${ }^{28}$

How much might the cultural imagery that the commission was able to draw on have contributed to the difficult goal of reconciliation? Ebrahim Moosa and Piet Meiring both noted the strongly Christian and religious framework that gave resonance to the workings of the commission. ${ }^{29}$ This was possible because a majority of South Africans adhered to some denomination of Christianity, or to other religious communities, including Muslims, Hindus, Buddhists, Bahais, Jews and African traditionalists. Besides Archbishop Tutu, four of the 16 commissioners were pastors, while others were activists with close ties to ecumenical bodies. The 'faith communities' were involved from the very beginning in discussions about how the TRC should be constituted; they had a special hearing within the TRC in November 1997, in which representatives were invited to contribute their own insights and beliefs with regard to defining reconciliation, justice, accountability and restitution, and how these might be achieved. They were also asked to speak about their own experiences of apartheid, and many of their proposals were incorporated into the final report. ${ }^{30}$

So much overtly Christian or religious reference did not work for everybody, however, especially some members of the South African Communist Party who

27 For fuller explorations of the anthropology of performance, and the intersections between theatre and life, see especially Turner, Victor 1983, From Ritual to Theatre, PAJ Publications, New York; Turner, Victor 1987, The Anthropology of Performance, PAJ Publications, New York; Schechner, Richard 1985, Between Theater and Anthropology, University of Pennsylvania Press, Philadelphia; Schechner, Richard 1993, The Future of Ritual, Routledge, London; Barba, Eugenio 1995, The Paper Canoe: A guide to theatre anthropology, Routledge, London; and Carlson, Marvin 2003, The Haunted Stage: The theatre as memory machine, University of Michigan Press, Ann Arbor.

28 Minow, 'The hope for healing'; Marlin-Curiel, Stephanie 2002, 'Truth and consequences: art in response to the truth and reconciliation commission', in Richard CándidaSmith (ed.), Art and the Performance of Memory: Sounds and gestures of recollection, Routledge,London, pp. 37-62; Marlin-Curiel, Stephanie 2007, 'Recollecting the collective: mediatised memory and the South African Truth and Reconciliation Commission', in F. Guerin and R. Hallas (eds), The Image and the Witness: Trauma, memory and visual culture, Wallflower Press, London and New York, p. 69. Marlin-Curiel notes, all the same, that in the South African TRC, the role expected of the audience remained inexplicit and ambiguous, while the attention of the media was focused overwhelmingly on the testifiers, 'reinforcing a scenography of spectacle rather than a participatory and transformative ritual' (p. 70). The ritual qualities of the proceedings are also thoughtfully commented on by Bozzoli, Barbara 1998, 'Public ritual and private transition: the truth commission in Alexandra Township, South Africa 1996', African Studies, vol. 57, no. 2, pp. 167-95.

29 Moosa, Ebrahim 2000, 'Truth and reconciliation as performance: spectres of eucharistic redemption', in Villa-Vilencio and Verwoerd, Looking Back, Reaching Forward, pp. 113-22; Meiring, Piet 2000, 'The Baruti versus the lawyers: the role of religion in the TRC process', in Villa-Vilencio and Verwoerd, Looking Back, Reaching Forward, pp. 123-31.

30 Meiring, 'The Baruti versus the lawyers', p. 130. 
had played committed roles in the anti-apartheid struggle. Even one of the commissioners, Fazel Randera, objected as a lawyer to the religious tone of the proceedings, which he felt ought to be conducted in a style more in keeping with the fact that the TRC was intended to be a legal process. He asked that the hearing at the Johannesburg office in 1996 should begin, not with prayers, but with half a minute's silence. Although Tutu agreed, when it came to it he found this so uncomfortable that he was unable to begin until he had led the audience in prayer. ${ }^{31}$ Meiring noted that there were many occasions when in moments of great anguish, the proceedings were eased by singing or praying. ${ }^{32}$ Tutu himself played a major role in guiding the entire process, insisting on the spiritual necessity to re-establish a moral order through confession, mercy and forgiveness - ideas with profound resonances in Christianity. He repeatedly urged perpetrators and organisations to apologise for injustices and pleaded with white political, professional and business leaders to express remorse. ${ }^{33}$ Beyond the Christian framework, he furthermore maintained that 'restorative justice was consistent with the African social tradition of ubuntu that placed a premium on harmony, friendliness, and community' ${ }^{34}$

These accounts give us a vivid sense of how strongly the TRC's effectiveness was to rest on its performative elements and how the participants at times were feeling their way in uncharted territory. Symbolic and ceremonial elements of the meetings, carefully chosen to create a space in which order, calm and a sense of emotional support might prevail, acted here, as in any ritual, to condense meanings and to channel and focus emotions. These arrangements included even incidental details such as flowers and white tablecloths. ${ }^{35}$ Arguably, the newness of the event made these qualities especially crucial. There was no precise script to follow, so the commission had to create the right atmosphere of solemnity, empathy and authority as it went along. Moosa stresses this performative quality - a quality of 'as if':

Can one say that the TRC fulfilled the role of 'as if' (that is, as if it were some kind of court of justice). 'As if' it performed the function of Nuremberg. As if reconciliation between antagonistic racial groups had occurred. As if the truth were disclosed. The motif that repeatedly comes to mind is that of 'as if': a simulacrum? The TRC played the role as if it were taking confession and offering redemption. ${ }^{36}$

31 Ibid., pp. 123-4

32 Ibid., p. 126.

33 Amstutz, Mark 2005, The Healing of Nations: The promise and limits of political forgiveness, Rowman and Littlefield, Lanham, pp. 204-5.

34 Ibid., p. 112.

35 Bozzoli, 'Public ritual and private transition', p. 170.

36 Moosa, 'Truth and reconciliation as performance', p. 117. 
By this account, the commission had to will itself to succeed. Reflecting on what the TRC dared to achieve through its own drama, one could see even more clearly the significance of a charismatic and authoritative figure such as Tutu, one who was able to guide and draw meaning from what was happening, with all of its unpredictable outpourings of emotion, which as Moosa stated, made it 'an awesome experience, one that made people truly tremble'. He declares the commission to have functioned as a sort of 'secular Eucharist', offering a miracle (of negotiation), a mystery (the uncovering of the hidden past), the 'Word' (the report) and even the power to grant redemption to those sinners who offered full confessions. It created a theatre in which South Africa's disenfranchised made the sacrifice of dramatising or re-performing their own suffering in an effort to enable 'a redemption of the sins of apartheid'. ${ }^{37}$ As incomplete as the process has inevitably remained, he concludes, the commission's final report will continue to be a powerful element in social memory, to be drawn on and invoked as a landmark and reminder in the continuing development of reconciliation.

\section{Indonesia: islah and the case of the Tanjung Priok massacre}

Clearly, Christianity provided South Africans with a source of resonant moral concepts and shared imagery that had the potential to infuse the workings of the TRC with sacredness and solemnity. Reconciliation is too important, however, and perhaps too universal an idea to exist within only a single framework. In fact, the International Centre for Transitional Justice (ICTJ) in its web site article on this subject stresses the importance of not tying reconciliation to any particular set of religious ideas. ${ }^{38}$ It therefore chooses to articulate it in terms of the practical necessity of re-establishing basic security and a more cultureneutral model of 'civic trust' as something that has to be developed (or reestablished) between citizens of the same political community, who might not know each other personally. This includes both 'horizontal' trust among citizens and 'vertical' trust between the citizens and their institutions. The latter means being able to know that participants in the institution share rules, values and norms that they are prepared to regard as binding.

This expectation of a commitment to shared norms and values returns us, however, to the cultural element. Where commissions are held in countries that are not predominantly Christian, what other symbolic languages and frameworks can be brought to bear in the effort to lend weight to what they are doing? The example of predominantly Muslim Indonesia presents itself as a potentially

37 Ibid., p. 117-19.

38 See <http://www.ictj.org/en/tj/784.html> 
interesting one. Are there any specifically Muslim ideas that might resonate with enough people to be put to use in the quest for truth and justice about past atrocities there? Indonesian scholars Wahyudi and Fadjar Thufail offer insights into the recent pursuit of justice by victims of the Tanjung Priok massacre of 1984, including an analysis of the concept of islah and its deployment by members of the military to reach a settlement with victims. ${ }^{39}$

I have not found it easy to trace the background of the term 'islah' (literally, 'to repair') in Islam, or to get a sense of how widely or deeply this concept resonates with Muslims generally. The situation is complicated by the fact that it is also (more commonly) used in the sense of 'reform'. Wahyudi offers the following account:

The word islah is from the Arabic...Islah literally means to restore or to reform. In the Koran and Hadith, islah is usually used to refer to making peace between two people who are fighting or in dispute with each other...islah means the effort to achieve reconciliation. According to Islamic law, islah is a procedure that can only be used in civil cases, and not criminal cases...In addition, the term islah is sometimes used to mean 'to reform'... The point of this reformation movement was to return Islam to its original, genuine message. ${ }^{40}$

There is an emergent quality to the idea of islah in Indonesia, such that it has the potential to mean different things in different contexts. This is both a strength and a weakness. Priambudi Sulistiyanto and Rumekso Setyadi record its positive use in a workshop called the Victims' Forum held in Semarang, Central Java, in 2003. ${ }^{41}$ This event was organised by Syarikat, a non-governmental organisation formed by younger members of Nahdlatul Ulama with the goal of reaching out to ex-TAPOL, victims of the 1965-66 purges of alleged communists. ${ }^{42}$ Some of the Kyai or religious teachers who spoke at this forum were at pains to stress

\footnotetext{
39 I mentored Wahyudi when he visited the Asia Research Institute, National University of Singapore, as a regional visiting scholar in 2007, and am indebted to him for permission to cite his work in the following account: Wahyudi 2007, 'Sakralisasi Ideologi Memakan Korban: Kuasa dan Ritus Kekerasan Orde Baru di Balik Tragedi Tanjung Priok 1984', in Zainal Rahman (ed.), Pergumulan Negara Bangsa Yang Tak Kunjung Usai, Politea, Yogyakarta; and What's the point of remembering? Islah as the altering of memory among the victims of the Tanjung Priok massacre in the post-Soeharto era in Indonesia, Paper presented at the Asia Research Institute Graduate Seminar, 28 July 2007. See also Fadjar, Thufail 2007, Transactions in the reconciliatory forum: Islah and the legacy of state violence in Indonesia, Paper presented at the Conference In Search of Reconciliation and Peace in Indonesia and East Timor, ARI, National University of Singapore, Singapore, 18-20 July 2007.

40 Wahyudi, What's the point of remembering?, n. 1.

41 Sulistiyanto and Setyadi, Civil society and grassroots reconciliation in Central Java, Indonesia, p. 6.

42 Nahdlatul Ulama is the country's largest Muslim association. Some of its members played an as yet little examined role in carrying out the massacres of 1965-66. This initiative of today's younger generation within the organisation is designed to open a dialogue and begin to offer some redress. TAPOL is an acronym for Tahanan Politik, or political detainees from this period, more than 1 million of whom were held for years without trial; their families were also stigmatised.
} 
the more than 30 verses of the Koran that advocate mercy and forgiveness and denounce revenge. K. H. Syamsudin was one of those who explained that islah meant 'peace' — not just a mechanism for making peace but a feeling that must start in the heart before reaching out to society as a whole. In the context of continuing efforts to investigate the Tanjung Priok massacre, however, it was deployed very differently.

As Wahyudi describes, on 10 September 1984, police arrested four Muslims of Kampung Koja, Tanjung Priok, after an altercation between them and neighbourhood security officers, one of whom had disrespectfully entered a local mosque without removing his shoes. Two nights later, when residents demonstrated for the release of those arrested, the military opened fire on the demonstrators and killed more than 300 people. Others were held without trial for years, including some innocent bystanders. Non-governmental organisations claim that more than 100 people are still missing or unaccounted for. ${ }^{43}$ Twenty-eight of the demonstrators were tried and sentenced in 1985-86 on charges of 'provoking' street demonstrations, attacking security officers, spreading a radical Islamic agenda and challenging the State's ideology of Pancasila. For the Suharto regime, the trials provided a useful means of silencing opposition in subsequent years, and no further investigation was ever permitted. ${ }^{44}$ Therefore, the families of those who had died or been arrested were unable to make any inquiries about what had happened to their family members or bring any charges against the government concerning its responsibility. Indeed, they were themselves stigmatised as subversives.

As soon as Suharto fell from power, however, survivors organised to lobby for an investigation into the massacre. President B. J. Habibie swiftly released many of Suharto's political prisoners, including those associated with Tanjung Priok, and a coalition was formed between former political prisoners, the victims and their relatives, and human rights organisations. They called on the government to reopen the case and bring the perpetrators to trial. ${ }^{45}$ A number of high-ranking military figures, including Generals Benny Moerdani and Try Soetrisno, as well as Golkar Party members, had been involved in the massacre and were understandably unenthusiastic about such a possibility. A proposal by the National Commission of Human Rights to establish a TRC instead only strengthened the victims' determination to press for a trial.

On 1 September 1998, the Indonesian Legislative Assembly decided to constitute a joint fact-finding commission with members drawn from different

\footnotetext{
43 Fadjar, Transactions in the reconciliatory forum, p. 1.

44 For a fuller discussion of this aspect of the affair, see Burns, Peter 1989, 'The post Priok trials: religious principles and legal issues', Indonesia, vol. 47, pp. 61-88.

45 See Sulistiyanto, Priambudi 2007, 'Politics of justice and reconciliation in post-Suharto Indonesia', Journal of Contemporary Asia, vol. 37, no. 1, pp. 73-94.
} 
political factions. In the meantime, the victims had also been collecting evidence themselves, which they presented to the National Commission of Human Rights in October. In March 1999, the commission recommended to the government that the case should go to court. By September 2000, the commission's fact-finding team had interviewed 90 witnesses and called on high-ranking members of the military to give testimony. The survivors became distrustful, however, when the team surveyed, but failed to excavate, the sites of mass graves. Furthermore, in their final report, they claimed that the massacre had happened because Muslim residents of Tanjung Priok were themselves resisting the troops. This led to protest demonstrations, prompting President Wahid to order the AttorneyGeneral's Office to renew investigations. A new team then proceeded to exhume a number of graves in cemeteries throughout Jakarta. The forensic experts' preliminary report indicated that the number of victims was much greater than the military's estimate.

In the meantime, a new development occurred that caused a split between the survivors. Some of them accepted an offer of reconciliation made by members of the military, led by General Soetrisno himself. An islah agreement was held on 1 March 2001 at the Sunda Kelapa Mosque, at which the 86 victims and survivors were represented by only seven individuals. What sorts of language or concepts were deployed around this event? According to Fadjar, Soetrisno is on record as saying that '[i]slah helps resolve the Tanjung Priok case. Then both parties [to the agreement] will strengthen their family ties [hubungan kekeluargaan] and sustain silaturahmi ['good relations'], which has its roots in a meaningful social solidarity. ${ }^{46}$ In Fadjar's analysis, '[w] hether or not...islah really applies Islamic norms is entirely a different question', for what he finds significant about Soetrisno's statement is its emphasis on the desired resultsilaturahmi ('harmony', 'friendly or familial relations'). ${ }^{47}$ The statement thus exploits the language of a fictitious kinship. Fadjar appeared to see the framing of the islah agreement as entirely opportunistic: the invocation of Islamic norms served largely to make the event look 'less political', but he pointed out that representatives of major religious organisations were conspicuous by their absence. The only prominent Muslim figure to be present was the late Norcholis Majid, a well-known progressive Islamic intellectual. He, however, appeared to be there as an observer and played no active part in the proceedings apart from signing his name to the Piagam Islah (Islah Charter) drawn up by the military and signed by those present. This absence of participating religious figures presents a strong contrast with the South African case, as does the lack of an audience to represent the public. Nor did the survivors themselves have much of a role to play, since no negotiation took place during the meeting and all the speeches were made by the military. Their subsequent declarations that

46 Fadjar, Transactions in the reconciliatory forum, p. 1.

47 Ibid., p. 3. 
the islah agreement was successful must therefore be taken in context. This case has produced legal ambiguities of a different kind from those observed in South Africa. Notably, the Islah Charter is not in itself a legal process; yet, it has already had legal consequences, since a judge at the Ad Hoc Human Rights Court on Tanjung Priok has subsequently cited it in his judgment acquitting the military defendants.

The islah forum caused a dramatic rupture between the two groups of survivors. Those in favour of islah became known as the 'Pros', while those who opposed it were called the 'Cons'. Soetrisno and some of the other perpetrators set up a foundation called Yayasan Penerus Bangsa (a vacuous title roughly translatable as 'Association of Heirs of the Nation'), which distributed R300 million (approximately US\$30 000) and six trucks to the survivors. They also paid R2 million (approximately US\$200) to each victim's family. This money was disbursed without any consultation with the Tanjung Priok people themselves, and was termed at Soetrisno's insistence 'uang tanda kasih' ('goodwill money') and not 'uang ganti rugi' ('compensation money'). ${ }^{48}$ Since most of the survivors were living in poverty, the offer was sufficient temptation to some of them to make a settlement. 'In short,' writes Wahyudi, 'they were prepared to sell their memories to the perpetrators. ${ }^{49}$

Just a week after the islah agreement, President Wahid issued a presidential decree (no. 53/2001) on the establishment of Ad Hoc Human Rights Courts for Timor-Leste and Tanjung Priok. This created contestation among the victims. The 'Cons' group met with the president and told him that the islah agreement should not be used as a pretext to stop the trial; but the 'Pros', accompanied by Soetrisno, asked for it to be cancelled, since they now regarded the case as closed. They suggested that the Tanjung Priok islah agreement should even become a model for dealing with other human rights abuses in Indonesia. The president himself was ambivalent, but eventually he gave the order for the court to continue its work. ${ }^{50}$

Evidence given by the 'Pros' during the subsequent trial differed from what they had said in the Report of Judicial Investigation carried out by the National Commission of Human Rights. Now they attempted to protect the perpetrators' position or even retracted their earlier testimonies. When the Chief Justice questioned the victims about these retractions, they replied that they had already reconciled with the perpetrators through islah and asked that they be absolved. Even one of the 'Cons', Yusron Zainuri, ultimately retracted his testimony. His mother had fallen sick; lacking the money to pay her hospital bills, he accepted

48 Ibid., p. 4.

49 Wahyudi, What's the point of remembering?, p. 16.

50 Sulistiyanto, 'Politics of justice and reconciliation in post-Suharto Indonesia'. 
a loan from the perpetrators. Subsequently, he was no longer in a position to assist the prosecution, and he even asked the Chief Justice to strike off his earlier testimony in the Report of Judicial Investigation. Wahyudi learned from his interviews that a week before the trial opened, each of the survivors who had agreed to the islah settlement was presented with a new motorcycle. They would receive further payments if their testimony was satisfactory, and were even promised continued monthly support, on top of the sums they had already received in the islah agreement.

Thus the 'Pros' were motivated to perjure themselves and even to collude with the perpetrators by trying to intimidate the 'Cons' during the proceedings. The 'Cons', in Wahyudi's view, have consequently suffered four layers of trauma. First, they have suffered as a result of the past tragedy itself; second, from the stigmatisation that the State has inflicted on them for years; third, they feel terrorised by their fellow victims. Fourth, and most ironically, their years of struggle to prosecute the perpetrators in the end led to some of the victims themselves giving evidence that protected the perpetrators from being found guilty. The prosecution also failed the victims in that the case it presented was full of flaws and failed to establish the responsibility of the highest-ranking members of the military. Ultimately, only four convictions were obtained, all of which were overturned on appeal. ${ }^{51}$

The Ad Hoc Human Rights Court for Tanjung Priok represented the first possibility ever in Indonesia to bring to court a case of past rights abuses. As such, there were great hopes that this trial would lend momentum to the development of democratisation in Indonesia's era of transitional justice. Regrettably, islah seems instead to have been deployed cynically as a device to avoid any acknowledgment of wrongdoing. In sharp contrast with the South African case, here we see perpetrators, still in positions of power and influence, exploiting a superficially religious language in a move that has clearly been calculated to buy off enough of their victims to derail the movement that has been pressing for them to be held accountable. Effectively, they offered themselves an amnesty, conveniently avoiding any embarrassing requirement for disclosure, while the judiciary proved itself still too weak to prevent them.

\section{The deployment of traditional resources for reconciliation in Timor-Leste}

Pat Walsh, one of those closely involved in setting up the Commission for Reception, Truth and Reconciliation (CAVR) in Timor-Leste, has described the

51 Ibid., pp. 86-8. 
commission as 'an original, pioneering contribution to peace-building studies by the people of East Timor'.$^{52}$ CAVR was established in April 2002 and its final report, Chega! ('Enough!' in Portuguese) was published in March 2006. ${ }^{53}$

After the appallingly brutal decolonisation of 1999, the population of TimorLeste was left even more traumatised than before. According to Antonio Lopes, author of the CAVR's 2003 interim report, people were carrying a heavy burden of hidden grievances, pain and anger. ${ }^{54}$ The CAVR had no mandate to grant amnesties or to deal with serious crimes such as murder, rape or torture, but was planned to work in conjunction with the Serious Crimes Unit, to which such cases were to be referred. Some 250 Timorese staff members were employed in teams all over the country and collected 1541 statements, which were entered into a specially designed database and coded for systematic analysis. This was accompanied by 'community profiling' to map and record events of the 24-year period since decolonisation by the Portuguese (1974-99). As a community exercise, this served to draw people together to compile a common narrative, while helping to create a record for the future. ${ }^{55}$ Public hearings of the CAVR were held in Dili, concerning forced displacements, famine, political prisoners, women's roles in conflict, the roles played by international actors, conflicts between political parties and the effects on children. The hearings were televised, though it was relatively problematic to reach out to a scattered, remote and largely non-literate population. A Retrospective Mortality Survey was conducted in an effort to establish with greater accuracy how many people had died. The CAVR also organised a Healing Workshop, held in Dili in June 2003, with the help of civil society groups. This brought together 40 survivors from 11 districts (20 men and 20 women) and invited them to share their experiences through a mixture of painting, stories, drama, song, dance, prayer and reflection. Here we see an innovative attempt - even if on a small scale - to draw survivors together and create a supportive setting in which they could express their testimony in a variety of media.

\footnotetext{
52 Walsh served as an advisor on transitional justice to President Xanana Gusmao. The comment was made in a lecture he gave at the National University of Singapore in January 2007.

53 See Chega! ('Enough!'): Final report of the CAVR (Commission for Reception, Truth and Reconciliation in East Timor), 2006, <http://www.cavr-timorleste.org/chegaReport.htm>. Thoughtful assessments of its achievements can be found in Reiger, 'Hybrid attempts at accountability for serious crimes in Timore Leste', pp. 143-75, and Burgess, 'A new approach to restorative justice', pp. 176-205.

54 Lopes, Aniceto Guterres 2003, Report on the work of CAVR (Commission for Reception, Truth and Reconciliation in East Timor), Paper presented at the Institute for South-East Asian Studies, Singapore, 5 September 2003, p. 5. (At this point the CAVR was still in process.)

55 That a common narrative was still problematic was dramatised by the renewed crisis in Timor-Leste in 2006, and the assassination attempts of 11 February 2008. These events show that divisions - some of which date back to before the Indonesian invasion - have continued to fester not far beneath the surface. In particular, demobilisation of former independence fighters was not carried out in a way that was satisfactory to all parties, leaving many former fighters dangerously disaffected.
} 
The main work of the CAVR was to carry out Community Reconciliation Procedures (CRPs) in every district, with the aim of reintegrating lowlevel offenders. The framework chosen to shape these meetings was the adat (customary law) ceremony called 'biti bot' or 'unrolling of the mat'. The mat is laid out in a public space and the occasion is dignified by the display of sacred heirloom objects. The meeting is presided over by elders and spiritual leaders, who arrive dressed in ceremonial attire of traditional textiles, silver breastplates and headdresses of feathers or silver horns. They open the proceedings by chanting ritual verses, then take their places and share betel-nut - a gesture symbolic of good relations all over South-East Asia. The participants arrange themselves around the four sides of the mat, with the CRP panel on one side, facing the community members, and the deponents and victims to the panel's left and right respectively. The hearing requires a full admission and apology in the presence of the community. The victim confronts the perpetrator, is entitled to question them closely and must eventually say what will help them feel better. Perpetrators must then undertake redress as directed. According to Lopes, a major reason for the success of the CRPs has been this creative combination of traditional and formal procedures. The spiritual and cultural practices of particular regions deployed in each case 'give additional meaning and force to the process, in addition to giving the relevant communities a larger sense of ownership and participation'. ${ }^{56}$ This sensitivity to locally embedded traditions was combined with Catholic imagery in the exhortations that came from Nobel Peace Prize winner Bishop Carlos Belo (whose highly respected position in Timor-Leste somewhat paralleled that of Archbishop Tutu). He urged parishioners to 'go to the CAVR to confess their sins', and promoted a message of forgiveness based on religious beliefs, which could have contributed to some people's willingness to consider reconciliation. ${ }^{57}$

56 The authors of The Revival of Tradition in Indonesian Politics: The deployment of adat from colonialism to indigenism (Davidson, Jamie and Henley, David [eds] 2007, Routledge, London) record some parallel instances of the creative deployment of adat traditions in current Indonesian politics. Many areas suffering the aftereffects of the ethnic conflicts of 1999-2000 have tried to find means of creatively drawing on adat procedures for reconciliation. Birgit Bräuchler provides a particularly fascinating and complex example from Maluku (Kunci Perdamaian or mobilising tradition for peace: the Moluccan case, Paper presented at the Conference In Search of Reconciliation and Peace in Indonesia and East Timor, ARI, National University of Singapore, Singapore, 18-20 July 2007). Alcida Honwana provides a comparative example from rural Mozambique, where the mending of social divisions after 15 years of war has revolved around the use of traditional healing rituals. Within the Mozambican cosmology, health is defined as dependent on harmonious relations between humans themselves, between humans and nature, and between the communities of the living and the ancestors. Where psychiatric professionals are not in any case available, the role of traditional healing and purification rituals in helping individuals and communities come to terms with traumatic distress (whether as victim or perpetrator) can hardly be overestimated. Further, the spirits of those who died in the conflict and never received proper burial are believed to be vengeful and liable to torment the living; rituals can help to settle them peacefully in the spirit world. Many Mozambicans might have had recourse to a combination of ritual, religious and medical practices in the search for healing (Honwana, Alcida 1998, 'Sealing the past, facing the future: trauma healing in rural Mozambique', Conciliation Resources, <www.c-r.org >).

57 Burgess, 'A new approach to restorative justice', p. 202. 
Ultimately, the CAVR exceeded its planned goal of hearing 1000 cases. By the end, it had received a total of 1541 statements from deponents requesting to participate. Some 1371 of these cases were completed successfully through CRP hearings; 85 were retained by the Office of the General Prosecutor as potentially too serious to be dealt with by CRP; 32 further cases were adjourned during the hearings when evidence came to light that they too might involve 'serious criminal offences'. Thus, nearly 90 per cent of all cases were completed. This is an impressive achievement, especially given the CAVR's limited funding. Was its success perhaps due partly to the fact that in this instance (unlike South Africa) victims and perpetrators were not so polarised, being of the same community? Or was it because these, after all, were the smaller cases (though still quite serious), while bigger perpetrators remained unpunished - a fact that must also be seen as a limitation? While these procedures were still continuing, Lopes wrote optimistically:

Perpetrators of past wrongs also report that by publicly admitting their participation, apologizing and asking forgiveness, the limits and resentments in their relationships with their communities are lessened. As victims are given the right to accept or reject this request for forgiveness it reverses the power dynamic. This gives victims the first opportunity they have experienced to feel honoured and to have their pain and suffering honoured. We hope and believe that the combined effect of Community Reconciliation Procedures, public hearings, statement-taking, victims' hearings and community mapping exercises is to draw the community together to resolve past differences. In this way there is less likelihood of recurrence. ${ }^{58}$

A key feature of the biti bot is that once the mat has been unfurled, it cannot be rolled up until the disputes have been settled. ${ }^{59}$ Community members often showed themselves willing to remain at the hearing all day and far into the night, even going without dinner, until a reconciliation agreement had been reached. Some instances of community reconciliations recounted by Lopes illustrate a number of other features of the process: the importance of admitting responsibility and apologising; the rather mild requirements for compensation or community service; and the dramaturgical force of traditional sacrificial rituals accompanied by communal meals, by which the 'unrolling of the mat' is concluded. ${ }^{60}$ Non-Timorese members of the panels often expressed their surprise

\footnotetext{
58 Lopes, Report on the work of CAVR, pp. 5-6.

59 Burgess, 'A new approach to restorative justice', p. 189.

60 Lopes, Report on the work of CAVR, pp. 8-9. Lopes gives examples of the outcomes of several cases, of which the following extracts serve to illustrate both the sorts of crimes committed, and the nature of the penalties agreed to: '30 June 2003: Bobonaro - Odomau: 3 Deponents, Victims, community. Reasons for Hearing: Militia membership, performing ceremonies for militia, involvement in Indonesian police service, house burning, destruction of property. Community Reconciliation Act: Community service cleaning church 1 day a week for 3 months, payment of one sacrificial pig. Apologise, bound not to repeat.' '5 July 2003:
} 
at the very minor reparations requested by victims. These often amounted to only a symbolic payment of rice, salt, palm wine or a pig or goat to be sacrificed for the communal meal, or two or three months' community service. Not all reconciliations, however, were successful. One thing that had not been fully anticipated at the beginning of the CAVR's work was that according to the biti bot tradition, the consent of victims was required for any settlement. The law did not strictly require the victim's consent, but adat did. The deponents understood the adat principle and did not raise complaints in instances where the victim would not be reconciled. Those cases were referred back to the Office of the General Prosecutor. ${ }^{61}$

Community Reconciliation Procedures continued until March 2004. By that time, the final report estimated, 30-40 000 community members had attended and participated in the hearings. The feedback from those interviewed was generally very positive about the social effectiveness of the CRPs. Many victims said that they valued the hearings chiefly because they had given them the opportunity to question perpetrators closely and to understand the motivations and circumstances surrounding their actions; they were generally less interested in punishment than in whether the perpetrator showed signs of remorse and their apology was considered to be heartfelt. They also said that the incorporation of traditional ritual procedures had reinforced the agreement to reconcile and that forgiveness and repentance were taken more seriously within this ceremonial context. ${ }^{62}$ That the CAVR managed to process so many cases quickly, cheaply and with this degree of community involvement is a very considerable achievement. The main objection to the proceedings seems to have come from those whose cases were still outstanding after the commission was closed; some communities have subsequently continued such events on their own initiative. As Burgess points out, whatever its shortcomings, 'the "quasilegal" program of CRPs has been the only visible face of the justice system at village level' in Timor-Leste. ${ }^{63}$

\section{Conclusion}

Each of my three examples illustrates a certain imaginative use of concepts having a bearing on reconciliation, in very different cultural contexts. All point to the ritual, performative or dramaturgical qualities of reconciliation processes, even where these are at the same time quasi-legal processes, established by

\footnotetext{
Oecussi - Bana Ufe: 2 Deponents, 2 Victims, community. Reasons for Hearing: House burning. Community Reconciliation Act: Symbolic payment of rice, salt, 2 pigs, palm wine for communal meal. Apologise, bound not to repeat.'

61 Burgess, 'A new approach to restorative justice', p. 191.

62 Ibid., pp. 187-8.

63 Ibid., p. 191.
} 
legal authority. Religion or the sacredness of traditional adat rituals is invoked in order to lend solemnity or effectiveness to the proceedings, to make them morally binding and to effect (or so it is hoped) a change of heart in those participating. The degree of success that each procedure can claim clearly differs widely. I have argued that while truth commissions might not always concern themselves with reconciliation, reconciliation is unlikely to be genuine unless it is accompanied by truth telling and admission of guilt. Success will also be greatly affected by external factors and the power relations prevailing at the moment of the staging of events of reconciliation. Whereas the South African TRC was a national organisation, sanctioned by law, and the Timorese CAVR was organised with international cooperation, each body acting as a third party in the proceedings, the example of the Indonesian islah agreement differs in that it was organised privately by the perpetrators, had no legal authority and was notable for its lack of either a third party to intervene between perpetrators and victims or an appropriately wide audience who might have assisted, in the manner I have discussed above, in achieving any genuine social transformation. In spite of its dubious status, however, this did not prevent it from having some impact on the legal proceedings that followed it.

Yet, even in spite of the failure of those proceedings to punish any of the perpetrators, Sulistiyanto manages to maintain a note of optimism. With regard to the recent efforts to try perpetrators of the Tanjung Priok massacre, he suggests that the fact that trials have been held at all - even if the few convictions obtained have been promptly overturned on appeal — still might have helped in some small measure to strengthen the shaky rule of law in Indonesia. As for the still-emergent concept of islah, its cynical deployment in the Tanjung Priok case should not, he proposes, lead us to dismiss altogether its future potential to assist in processes of reconciliation. Even if in this case the islah agreements failed to produce any convincing reconciliation 'because of their focus on forgetting the past instead of dealing with [it] in a comprehensive manner', the possibility remains, in a religious society such as Indonesia, that such ideas could come to play a useful role in future procedures for reconciliation. ${ }^{64}$ This will not happen, however, unless there is a greater commitment to disclosure, to breaking the culture of impunity and filling in the painful silences that remain in the national narrative. Those who opposed the idea of a truth commission because they preferred to see perpetrators sent to trial must be disillusioned by the inability of the courts to uphold convictions, while the hope of having a truth commission in conjunction with such trials has been dashed by the unexpected decision of the Constitutional Court in December 2006 to annul the 2004 Law on Truth and Reconciliation Commissions as unconstitutional. If there is to be further truth telling or reconciliation with regard to the traumas of the

64 Sulistiyanto, 'Politics of justice and reconciliation in post-Suharto Indonesia', p. 91. 
Suharto era, Indonesians will be obliged, for the time being at least, to find it through their own grassroots initiatives. ${ }^{65}$ Such initiatives, which to date have taken a variety of forms, including forums, exhibitions, documentary films and theatre workshops, are themselves culturally innovative and worthy of further study.

I have stressed the importance of the performative quality of these events as intrinsic to what they can achieve, but we have to recognise that whether the performers are acting in good or bad faith is an open question in any instance of reconciliation proceedings. The meaning of reconciliation will be to some extent dependent on context, and as the Indonesian example shows, we should not simply assume that every 'alternative' procedure devised to achieve it is necessarily benign. Nor should it be taken for granted that every recourse to traditional processes will necessarily be empowering or fair. ${ }^{66}$ In each new case where a TRC might be proposed in future, however, more innovation will be required, and the process will surely work best if its qualities and potentials as ritual are recognised. Above all, it must be flexible enough to respond to particular local conditions and to draw creatively on appropriate concepts that already have cultural resonance for the participants. As a transnational paradigm of truth and reconciliation commissions slowly becomes established, it remains important, therefore, not to assume that one universal model will ever work for everybody, but rather to pay attention to the local dimensions of what must always, in any particular instance, be a cultural process.

65 Sulistiyanto and Rumekso, Civil society and grassroots reconciliation in Central Java.

66 van Zyl, Paul 2005, 'Dealing with the past: reflections on South Africa, East Timor and Indonesia', in Zurburchen, Beginning to Remember, p. 340. 
